\title{
THE TWO CULTURES AND THE SCIENTIFIC REVOLUTION
}

GIR CHARLES P. SNOW'S Rede Lecture* for $\$ 1959$ carries forward to a significant extent the old arguments concerning those subjects commonly spoken of as the humanities on one hand and the sciences on the other. The teaching of the history and sociology of science to arts students and the teaching of the history of art and literature to science students is better than nothing, though it is difficult to see how the history of science can make much impact without a knowledge of the methods and results of scientific investigation. The corpus of knowledge of all types is now so vast that it is foolish to look back to a Hellenic or Thomistic attempt at a synthesis.

Sir Charles Snow is both a literary man and a scientist and is able to see each side of the problem from the other. He seems to find the smug, selfcontentment of many of the literary men more dangerous and irritating than the failure of some scientists to realize the implications of their own work in the broader field of human knowledge and aspiration. "Why do most writers take on social opinions which would have been thought distinetly uncivilized and démodé at the time of the Plantagenets? Wasn't that true of most of the famous twentiethcentury writers? Yeats, Pound, Wyndham Lewis, nine out of ten of those who have dominated literary sensibility in our time-were they not only politically silly, but politically wicked ? Didn't the influence of all they represent bring Auschwitz that much nearer ?"

But it is ill-considered of scientists to judge writers on the evidence of the period 1914-50. Literature changes more slowly than science. It has not the same automatic corrective and so its misguided periods are longer.

"At one pole, the scientific culture really is a culture, not only in an intellectual but also in an anthropological sense. Its members need not always completely understand each other-biologists more often than not will have a pretty hazy idea of contemporary physics-but there are common attitudes, common standards and patterns of behaviour, common approaches and assumptions. This goes surprisingly wide and deep. It cuts across other mental patterns, such as those of religion or politics or class. . . . In their working, and in much of their emotional life, their attitudes are closer to other scientists who in religion or politics or class have the same labels as themselves. At the other pole, the spread of attitudes is wider. It is obvious that between the two, as one moves through intellectual society from the physicists to the literary intellectuals, there are all kinds of tones of feeling on the way. But I believe the pole of total incomprehension of science radiates its influence on all the rest. That total incomprehension gives, much more pervasively than we realize, living in it, an unscientific flavour to the whole 'traditional' culture, and that unscientific flavour is often, much more than we admit, on the point of turning antiscientific ... Once or twice I have been provoked (by the 'non-scientists') and have asked the company how many of them could describe the Second Law of

\footnotetext{
* Published by the Cambridge University Press.
}

Thermodynamics. The response was cold: it was also negative. Yet I was asking something which is the scientific equivalent of: Have you read any work of Shakespeare's ?"

Little purpose is served by cataloguing the dismal ignorances in many arts people of the simplest, fundamental principles of science. "The separation between the scientists and non-scientists is much less bridgeable among the young than it was thirty years ago ; then they managed a kind of frozen smile across the gulf. Now the politeness has gone and they just make faces. It is not only that the young scientists now feel that they are a part of a culture on the rise while the other is in retreat. It is also, to be brutal, that the young scientists know that with an indifferent degree they will get a comfortable job while their contemporaries and counterparts in English or History will be lucky to earn 60 per cent as much. No young scientist of any talent would feel that he is not wanted or that his work is ridiculous as did the hero of Lucky Jim; and in fact some of the disgruntlement of Amis and his associates is the disgruntlement of the under-employed arts graduates."

Sir Charles insists that we should completely rethink our education. "Nearly everyone will agree that our school education is too specialized. But nearly everyone feels that it is outside the will of man to alter it. Other countries are as dissatisfied with their education as we are, but are not so resigned. Because of our intense specialization, alleged by schoolmasters to be dictated by the Oxford and Cambridge Scholarship examinations, we have set ourselves the task of producing a tiny élite-far smaller proportionately than in any comparable country-educated in one academic skill." Snow takes as an example the old Cambridge Tripos which seemed to be perfect in all respects save one. The one exception was-so the young creative mathematicians, such as Hardy and Littlewood, kept saying -that the training has no intellectual merit at all. They went a little further and said that the Tripos had killed serious mathematics in England stone dead for a hundred years.

While we are beginning, after many years, to understand the scientific and social implications of the industrial revolution and to understand the development in teaching technology in Germany in the nineteenth century and in the United States and U.S.S.R. in later years, we are still far from grasping the meaning of the scientific revolution, by which is meant the transformations made in industry and its effects because of electronics, atomic energy, automation and modern forms of machine tools.

We have failed to keep pace with the new scientific revolution-"roughly if we compare like with like and put scientists and engineers together we are training at a professional level per head of the population one Englishman to every one and a half Americans to every two and a half Russians. In Russia the gap between the cultures does not seem to be as wide as it is with us. If one reads contemporary Soviet novels, for example, one finds that their novelists can assume in their readers-as we cannot 
-at least a rudimentary acquaintance with what industry is all about". The latest figures of graduates trained per year (scientists and engineers combined) are roughly United Kingdom, 13,000 ; United States, 65,000 ; U.S.S.R., 130,000. One-third of Russian graduates in engineering are women. "It is one of our major follies that we do not in reality regard women as suitable for scientific careers. We thus divide our pool of potential talent by two."

"We are left with a population twice as large as we can grow food for, so that we are always going to be au fond more anxious than France or Sweden, and with very little in the way of natural resourcesby the standard of the great world powers, with nothing. The only real assets we have, in fact, are our wits. Those have served us pretty well, in two ways. We have a good deal of cunning, native or acquired, in the arts of getting on among ourselves : that is a strength, and we have been inventive and creative, possibly out of proportion to our numbers. Given these two assets, and they are our only ones, it should have been for us to understand the scientific revolution first, to educate ourselves to the limit and give a lead. In some fields, like atomic energy, we have done better than anyone could have predicted. Within the pattern, the rigid and erystallized pattern of our education and of the two cultures, we have been trying moderately hard to adjust ourselves. The historical warnings are all there. For instance, the Venetian Republic in its last half-century was guided by patriot men, who had immense political skill, who knew that the current of history had begun to flow against them. They were fond of the comfortable pattern of their life, just as we are fond of ours. They never found the will to break it."

There is yet another danger. The large masses of poor in the undeveloped countries will not allow themselves to live for ever in a world in which large sections have become rich through industry. A new missionary spirit, both human and technical, is essential.

"Closing the gap between our cultures is a necessity in the most abstract intellectual sense, as well as in the most practical. When those two senses have grown apart, then no society is going to be able to think with wisdom. For the sake of the intellectual life, for the sake of this country's special danger, for the sake of the western society living precariously rich among the poor, for the sake of the poor who need not be poor if there is intelligence in the world, it is obligatory for us and the Americans and the whole West to look at our education with fresh eyes. This is one of the cases where we and the Americans have the most to learn from each other. We have each a good deal to learn from the Russians, if we are not too proud. Incidentally, the Russians have a good deal to learn from us too." W. L. StMrNer

\section{COAL SCIENCE}

$\mathrm{T}$ HE third biennial International Conference on Coal Science was held at Valkenburg, in the Netherlands, during April 27-30. The Municipality kindly allowed the Conference to be held in the Municipal Theatre, and the greatest hospitality and interest were shown throughout by the burgomaster, F. A. A. H. Breekpot.

On this occasion the number of participating countries increased to fourteen, newcomers being East Germany, Czechoslovakia, Australia and India. Authors submitting papers were required to complete a form indicating, in telegraphic style, their main new conclusions and results, the methods and observations from which these were deduced, and any special limitations or assumptions involved in their interpretation. This information was found by the organizers to be more helpful than the conventional summary (or on occasions the paper itself) in deciding whether a paper was acceptable; it was also useful in evaluating the conclusions of the Conference and the interrelation of papers. The proceedings of this Conference will not be published as a whole ; but papers will be submitted by their authors to journals of their own choosing.

Discussion was unusually lively and fruitful, and a large proportion of novel work was presented. In several cases widely accepted ideas were apparently undermined, though it would be premature to assess the importance of the new evidence. For example, a suggestion arose, from the work of $\mathbf{S}$. Ergun and I. Wender on the $\mathrm{X}$-ray scattering of vitrinites reduced with lithium in ethylene diamine, that partially reduced aromatic and/or alicyclic molecules may lead to reflexions in the angular region where the (10) and (11) reflexions of aromatic mole- cules occur. This awaits direct experimental test, but if correct it may throw doubt upon the derivation of aromatic layer sizes in coal, for example, by Hirsch and Diamond. Ergun and Wender also demonstrated an increase of layer-spacing on reduction, even in graphite.

Similarly, an interpretation of data obtained on coal by high-resolution magnetic resonance spectroscopy, by J. K. Brown, W. R. Ladner and N. Sheppard, yielded a structural distribution of nonaromatic earbon atoms which may prove incompatible with the present consensus of opinion on the chemical structure of coal. As a third example, R. L. Bond and D. H. T. Spencer illustrated the inadequacy of existing interpretations of sorption data obtained with inert gases on coal and of heats of wetting of coal in polar liquids; a question thought by many to have been settled, at least in principle.

These, and the other thirty-three papers presented, were grouped under four heads, as follows.

\section{Chemical Reactions of Coal}

E. S. Hammack, H. G. Davis and F. B. Brown estimated the content of phenolic hydroxyl in vitrains by titration with sodium aminoethoxide in ethylene diamine, by trimethylsylylation and by acetvlation. They found reasonable agreement between these methods and noted the importance of particle size. Acetylation was studied by S. Delavareme, A. Halleux and H. Tschamler, who also confirmed the presence of quinone groups in coal extracts, by reductive acetylation and reduction with copper/ hydrogen sulphide. They observed the corresponding changes in the infra-red spectra and showed that the 